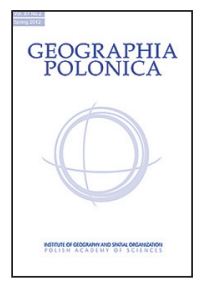

\title{
ANALYSIS OF LAND USE CHANGES OF URBAN VENTILATION CORRIDORS IN WARSAW IN 1992-2015
}

\author{
Katarzyna Osińska-Skotak • Joanna Zawalich \\ Warsaw University of Technology, Faculty of Geodesy and Cartography \\ Department of Photogrammetry, Remote Sensing and Spatial Information Systems \\ pl. Politechniki 1, 00-661 Warsaw: Poland \\ e-mail: k.osinska-skotak@gik.pw.edu.pl
}

\begin{abstract}
One of the most important factors influencing a city's climate is the ventilation of a given urban unit. The most effective avenue of wind penetration into a built-up area is provided by uninterrupted urban greenery, thoroughfares and railway land radiating from the city centre as well as river valleys cutting through the entire city creating a unified system. These areas are called urban ventilation corridors or urban ventilation wedges. In Warsaw such an air exchange and regeneration system has been under development since the 19th century. The aim of this paper is to illustrate the rate and direction of land use changes in 1992-2015 and indicate the cause of current changes in the development of ventilation corridors in Warsaw. Visual interpretation of SPOT and LANDSAT satellite images and aerial orthophotomaps provided the data source for a database on the state of development of the ventilation corridors in time series. The analysis carried out established that the built-up area mostly spreads at the expense of agricultural land, which can negatively influence the way the parts of ventilation system operate. Moreover, different analyses were conducted in order to discover the cause of the changes, including analysis of the local zoning plans which were in force at the time in question.
\end{abstract}

\section{Key words}

urban ventilation corridors - Warsaw - land use change $\cdot$ LANDSAT $・$ SPOT

\section{Introduction}

It has been almost 200 years since research on city climates started being carried out in Europe in order to investigate their huge impact on the way the city and its inhabitants function (Fortuniak \& Kłysik 2008). The monograph "The Climate of London..." in two volumes by Howard (1818-1820) is considered to be the first study on the climate of cities. Spontaneous development, especially during the industrial revolution of the 19th and first part of the 20th century, caused several negative processes such as excessive building density and, associated with this, a small share of green space, worsening 
of sanitary conditions, high level of air pollution, as well as modifications of the temperature and wind regimes fields (Oke 1981; Lewińska 1991; Voogt 2002; Arnfield 2003; Gaffin et al. 2008). The need for a 'healing' climate in the city has been mentioned since the turn of the 19th century, when the first schemes based on socialist ideas appeared (R. Owen, Ch. Fourier). They presented the concepts of the structural and functional division of the city (E. Howard, T. Fritsch, C. Perry) (Howard 1898; Malisz 1981; Chmielewski 2001). In the 1970s the concept of sustainable development emerged (Meadows et al. 1972). Thus the environment was recognised to be equally as important an issue as socio-economic development, taking into consideration the global scale as well as the local one. In numerous cities, however, faulty planning processes used up until the present day cause irreversible transformations which disrupt the local climate.

One of the most important factors influencing the city's climate is the ventilation of a given urban unit. The wind's ability to penetrate the city depends on features such as air humidity and temperature, transpiration intensity, cloud cover, precipitation and pollution (Oke 1982, 1987; Lewińska 1991; Bottema 1997; Haeger-Eugensson \& Holmer 1999). The development and transformation of urban areas modifies the city's meteorology and urban climate, especially the climate of the urban canopy layer (Landsberg 1981; Oke 1987). Temperature and wind regimes are modified in built-up areas, as in other areas (Kossowska-Cezak 1998; Kossowska-Cezak \& Bareja 1998; Błażejczyk 2002). For example, in Warsaw, the mean wind speed in the city centre reached $78 \%$ of that noted on the outskirts in the 1950s, while in the late 1970s the wind speed in the centre was reduced to $43 \%$, while in the summer and autumn it fell to 35\% (Kossowska-Cezak \& Bareja 1998; Błażejczyk 2002).

The most favourable land cover for wind penetration into the built-up area includes uninterrupted, continuous urban greenery, main roads and railway land which radiate from the city centre as well as river valleys cutting through the entire city. These areas are called urban ventilation corridors or urban ventilation wedges. Their location in a particular sector influences the way the city develops. Leaving the ventilation wedges intact prevents the city from spreading concentrically and is conducive to its development in a radial manner (Skorupski 2000). Furthermore, the need to connect the corridors to the major source areas (greenery outside the city's boundaries) prevents uncontrolled urban sprawl (Howard and Fritsch concepts). Due to their continuity, areas create an ecological network in the environment and maintain biodiversity (as they are the habitat of a number of different species). Moreover, the ventilation corridors also have a significant sanitary function. Their basic role is to enable air flow between the city and its surroundings, which is especially important during poor circulation weather conditions. As a result, pollution is dispersed and vapour is diluted (reducing the sultriness). Gases are absorbed within ventilation corridors, the air is cleansed of dust and the carbon-oxygen balance is maintained. The ventilation wedges (green areas) also reduce the lack of thermal comfort within the city as they diminish the urban heat island phenomenon (Kicińska \& Wawer 2010). In the urban greenery, the air is permeated by phytoncides because the airflow stimulates their emission. These antimicrobial volatile organic compounds (oils) contribute to negative air ionisation, which proves beneficial to human wellbeing (Lewińska 1991), reduces stress and blood pressure, alters autonomic activity, and boosts the functioning of the immune system, among other effects (Li et al. 2006, 2009). Furthermore, the urban greenery forming the ventilation wedges can perform a culture-forming function in a city, playing educational (creating approved attitudes towards the environment), social, psychological (e.g. recreation), aesthetic and symbolic roles. It also serves, when properly organised, as a place for recreation and entertainment. 


\section{The ventilation and air regeneration system in Warsaw}

The original establishment of the ventilation wedges in Warsaw was closely associated with the fortress laws from the period of the Warsaw Citadel. Settlement was gradually spreading along the main routes radiating from the city centre. Greenery emerged between the already built-up areas as building anything in that area was strictly forbidden due to the location of fortifications such as forts, batteries, reserve fire positions, dykes, warehouses etc. (Królikowski \& Ostrowski 2009).

The Warsaw Citadel was in operation during the years 1890-1915. It was a period of restricted urbanisation on the one hand and the emergence of ventilation corridors in Warsaw - due to rigorous fortress regulations - on the other, which is why Warsaw has a relatively clean environment.

Under the decree of Governor General Hans von Beseler of April 8th 1916, the administrative area of Warsaw was increased from 3244 ha to 11,483 ha (Królikowski \& Ostrowski 2009). Then a team of architects under the direction of Tadeusz Tołwiński formulated a "Preliminary draft of the regulating plan of Warsaw" (December 1, 1916) which emphasised the importance of greenery in the city. At the larger, city scale, it was the first attempt to officially establish a radial arrangement of green areas reaching to the inner city which played the role of ventilation corridors connecting suburban green space with the city centre. The allocation of these areas in such a manner was supposed to determine the future development of city districts, forcing them to spread out in a radial manner (Kotaszewicz 1994). In "Remarks on the preliminary draft of the regulating plan of Warsaw" the planned corridors mentioned above were given a verbal description. They consisted of green areas with a specific function, such as parks, cemeteries, gardens, reserve areas and walking routes. The plans from the Interwar Period preserved the concept of ventilation corridors. An isolation belt was also mentioned (Królikowski \& Ostrowski 2009) - based on the concept of 'a green belt', whose additional function was to prevent the city from uncontrolled spread. In the "Warsaw General Development Plan" from 1938 a ventilation system was mentioned and it comprised of eight ventilation wedges (green and open areas) half a kilometre wide and fourteen 'green drains' 100 meters wide all entering as far as the Warsaw city centre (Jankiewicz \& Porębska-Srebrna 2005).

Even though the plans during the Polish People's Republic (1952-1989) period did not relate back to the ideas of the Interwar Period, they shared the idea that it was crucial to preserve the continuity of the urban green area. Thus the "Capital City Voivodeship Plan" from 1978 established a need to connect the city greenery into one system together with the green areas beyond the city boundaries, which was supposed to result in the radial structure of the wedges including the Vistula River Valley (Skorupski 2000). The "Perspective General Development Plan of Warsaw", published in 1982, identified only ten open areas with the Vistula River Valley as an axis of the system. Their preservation from urbanisation was deemed of utmost importance, at the same time it emphasised the need to maintain their continuity (Skorupski 2000).

The first plan after the 1989 transformation was the "General Zoning Development Plan of the Capital City of Warsaw", published by the Warsaw Development Planning Office J.S.C. (pol. BPRW SA) and approved in 1992 by the City Council of Warsaw. The plan was the first prepared within the new legal - administrative and self-governing framework, which protects property rights. $A$ ventilation and air regeneration system was established in this document, which was designed to maintain proper climate and living conditions in the city. The system comprised nine ventilation wedges (Fig. 1): Bródnowski (1), Eastern-railway (2), Vistula (3), Wilanowski (4), Embankment (5), Mokotowski (6), Jerozolimski (7), Western-railway (8) and Bemowski (9). According to the plan, 
from 1992 the main development restrictions on the ventilation system area were to be: no pollution emitters to be located within the area, no mechanical and thermal barriers which could disturb air exchange can be erected, and it was also emphasised that it is necessary to treat all investment as a potential threat to the environment.

In the Eco-physiographic study attached to the "Strategic Concepts of Conditions and Directions for the Spatial Development of Warsaw" from 2006 (City Council of Warsaw 2006), currently legally binding, the principles in the plan published in 1992 were reit- erated. However, after a detailed comparison, discrepancies can be identified between the areas of particular wedges (Fig. 1). The area of several ventilation wedges has diminished and the study "An Assessment of the Ventilation and Air Regeneration System in Warsaw", prepared by Naftprojbud (2001) for the Spatial Planning and Architecture Department of the Warsaw Administrative Office, indicates that currently there are only five ventilation wedges that function properly, namely: Vistula, Embankment, Wilanowski, Easternrailway and Western-railway. The remaining ones mainly have an air regeneration

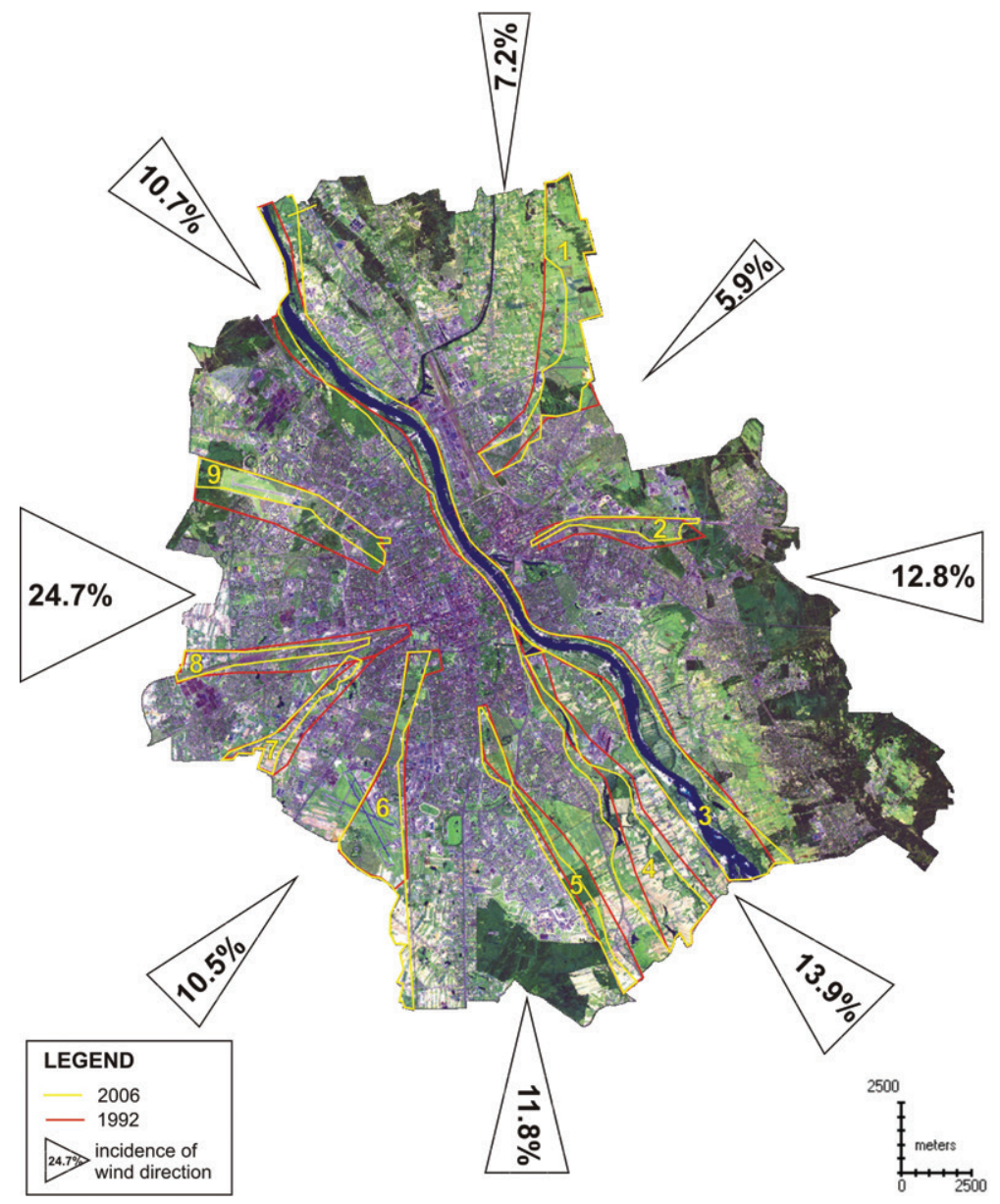

Figure 1. Comparison of the ventilation wedge system in Warsaw in 1992 and 2006 against the background of a LANDSAT satellite image from 2010 (prepared on the base of the General Zoning Development Plan of the Capital City of Warsaw 1992; Warsaw City Council 2006) 
function and are disturbed by recently erected buildings. Concerning the Bemowski and Bródnowski wedges, only 60 up to $70 \%$ of their area is of a good and very good ventilation class. It was pointed out that it is necessary to refrain from further development in the Mokotowski wedge and for the Embankment, Jerozolimski, Western-railway and Bemowski wedges it is advised that they remain in their current condition.

\section{Methodology and source data}

The aim of this study was an analysis of land use changes in the development of the Warsaw ventilation wedges. It was conducted with the use of satellite images and the scope of the analysis covered the area within the borders of the wedges established in the 1992 plan ("General Zoning..." 1992) as it was the first document prepared and passed after the political transformation in Poland and the first plan covering the whole area of Warsaw. Data from several satellites was obtained for the analysis, namely from: SPOT 2 (10.09.1992, pixel $10 \times 10 \mathrm{~m})$, Landsat 5 TM (14.06.2005, pixel $30 \times 30 \mathrm{~m})$, Landsat $7 \mathrm{ETM}+(07.05 .2000$, pixel $15 \times 15 \mathrm{~m})$, Landsat $8 \mathrm{OLI}$ (23.04.2015, pixel $15 \times 15 \mathrm{~m}$ ) and the aerial orthophotomap $(2010,2014)$. The images, with a spatial resolution of 10 to 15 metres, are sufficient for use in planning and land cover analysis for the assessment of the ventilation and air regeneration system. Therefore satellite images from LANDSAT (TM, ETM+ and OLI), archive orthophotomaps from zumi.pl, the GoogleEarth and geoportal.gov.pl portals as well as SPOT 5 satellite images (pixel $2.5 \times 2.5 \mathrm{~m}$ ) were used as supplementary sources in the analysis.

In this study the classic method of photointerpretation of colour composition based on satellite images was used. Ten categories of land use were distinguished: 1 - green areas (including high and low vegetation, allotment gardens, forested cemeteries), 2 - builtup areas, 3 - concreted ground and open ground, 4 - treeless cemetery, 5 - air ports, 6 - transport(main roads) and dykes, 7 - water, 8 - areas of riparian vegetation, 9 - railways and railway infrastructure, 10 - agricultural areas. Such a classification stemmed from the distinctive features of particular types of land cover on the satellite images. However, in order to facilitate the assessment of the land cover from the perspective of ventilation of a given urban structure, in the next step of this study the classification was narrowed down to four categories: 1 - green areas (including high and low vegetation, allotment gardens, cemeteries), 2 - agricultural areas, 3 - open space (concreted areas, ground, airports, communication areas, water, riversides and concrete banks, railway, sidings), 4 - built-up areas.

On the basis of this such areas were delimited as:

- those having a major contribution to air regeneration but also playing an important role in air exchange and enabling ventilation (class 1);

- regular agricultural areas, which help with air regeneration and ventilation (class 2);

- areas enabling airflow (class 3);

- built-up areas, decreasing the percentage of biologically active surface, as well as being a mechanical obstacle in the proper ventilation of the city (class 4).

Databases on the spatial development of ventilation wedges in Warsaw in the years: 1992, 2000, 2005, 2010, and 2015 were assembled from the visual interpretation of satellite imagery. All steps in the process were executed with use of ArcGIS software.

The following comparative analysis allowed the researchers to establish the character, rate and direction of current change in the development of ventilation corridors and identify those in which the most extensive and negative changes occurred, which in turn led to an assessment of whether they are endangered through poor management.

\section{Analysis of the results}

According to the "General Zoning Development Plan of the Capital City of Warsaw", approved by the City Council of Warsaw in 1992, the ventilation wedges constituted 
$18 \%$ of the city area within its current borders. The most extensive of the wedges - the Vistula River corridor, covers 2900 ha $(30 \%$ of the total area of the wedges) and serves as the axis of the ventilation and air regeneration system (Lorenc \& Mazur 2003). The ventilation wedges located on the right bank of the River Vistula account for $22 \%$ of the total area, while those on the left bank constitute $48 \%$. The next wedges after the Vistula River Valley corridor in terms of size, are the wedges of Bródnowski (ca. 1600 ha), Wilanowski (ca. 1100 ha) and Mokotowski (ca. 900 ha). The smallest is the Jerozolimski ventilation corridor - with only 380 ha (4\%). Open spaces (class 3) and agricultural areas (class 2) constitute the majority of the area ( $47 \%$ of the total). Over the period in question - 23 years - the built-up area increased by $35.5 \%$ and its share currently accounts for $23 \%$ of the area of the ventilation system in Warsaw (Fig. 2). In 1992 the built-up area accounted for $15 \%$ of the total area of the ventilation wedges.

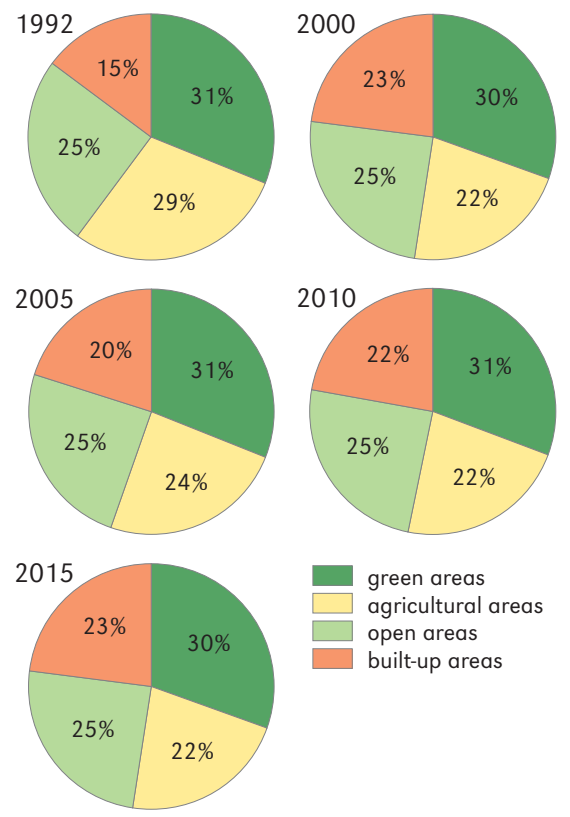

Figure 2. Share of particular land covers in the total area of the ventilation corridor system in Warsaw in the years 1992, 2000, 2005, 2010 and 2015
From an analysis of the share of the particular land cover from 1992 to 2015 it can be concluded that the share of green areas and open space within the wedges has not undergone any significant change. The increase in the built-up area mainly occurs at the expense of agricultural land. The trend appears to be stable taking into consideration all the ventilation corridors (Fig. 3). The rate of development in 1992-2010 can be estimated at 40 ha/year, while in 2010-2015 it was approx. 15 ha/year. Agricultural land decreased by 35 ha each year on average until 2010 and has diminished by 22\% since 1992. As a consequence green areas and open space decreased by 2 to 3 ha/year (1\%). In 2010-2015 the rate of decrease in the area of agricultural land only amounted to $6 \mathrm{ha} /$ year, while that of green areas decreased by 3 ha/year. However, the changes were different in each of the individual ventilation wedges in Warsaw (Figs. 4, 5), which is the result of their diverse development and ownership structure.

The Bemowski ventilation wedge is characterised by a lack of agriculture areas, thus the expansion of the built-up area has occurred at the expense of city greenery (Fig. 5). The

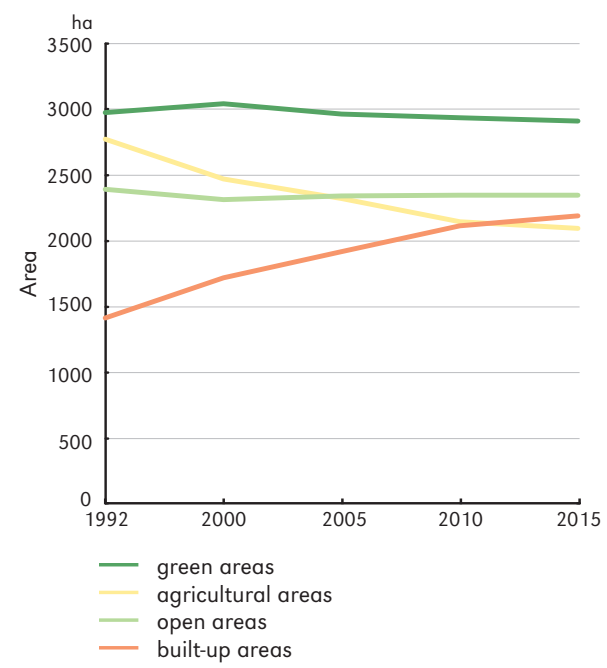

Figure 3. Changes in land use within the area of the ventilation wedges in Warsaw in the years 1992 to 2015 
most rapid changes took place in the years 2000-2005, as during this period alone the area of urbanised land increased by $7 \% \mathrm{com}$ pared to the year 2000 while green areas decreased by $5 \%$. Nevertheless, the changes were limited over the entire period of the analysis and can be estimated at the level of 0.5-2 ha/year (in comparison to the total area of the wedge of $912 \mathrm{ha}$ ).

In the Bródnowski wedge the increasing trend to further development has been particularly evident since 2000 (Fig. 5). On average the built-up area increased by 21 ha/year in the period 2000-2010, mainly at the expense of agricultural areas (14 ha/year) and green areas ( $6 \mathrm{ha} /$ year). The development of built-up areas still progressed in 2010 -2015, but its intensity decreased slightly (on average the built-up area increased by $6.5 \mathrm{ha}$ /year), which was caused by policy changes in the granting of mortgage loans. Within the 23 year period the total built-up area grew by a factor of 2.7. However, the remaining classes of land use are constantly decreasing with special emphasis on agricultural areas. Over the years 2005-2010 they

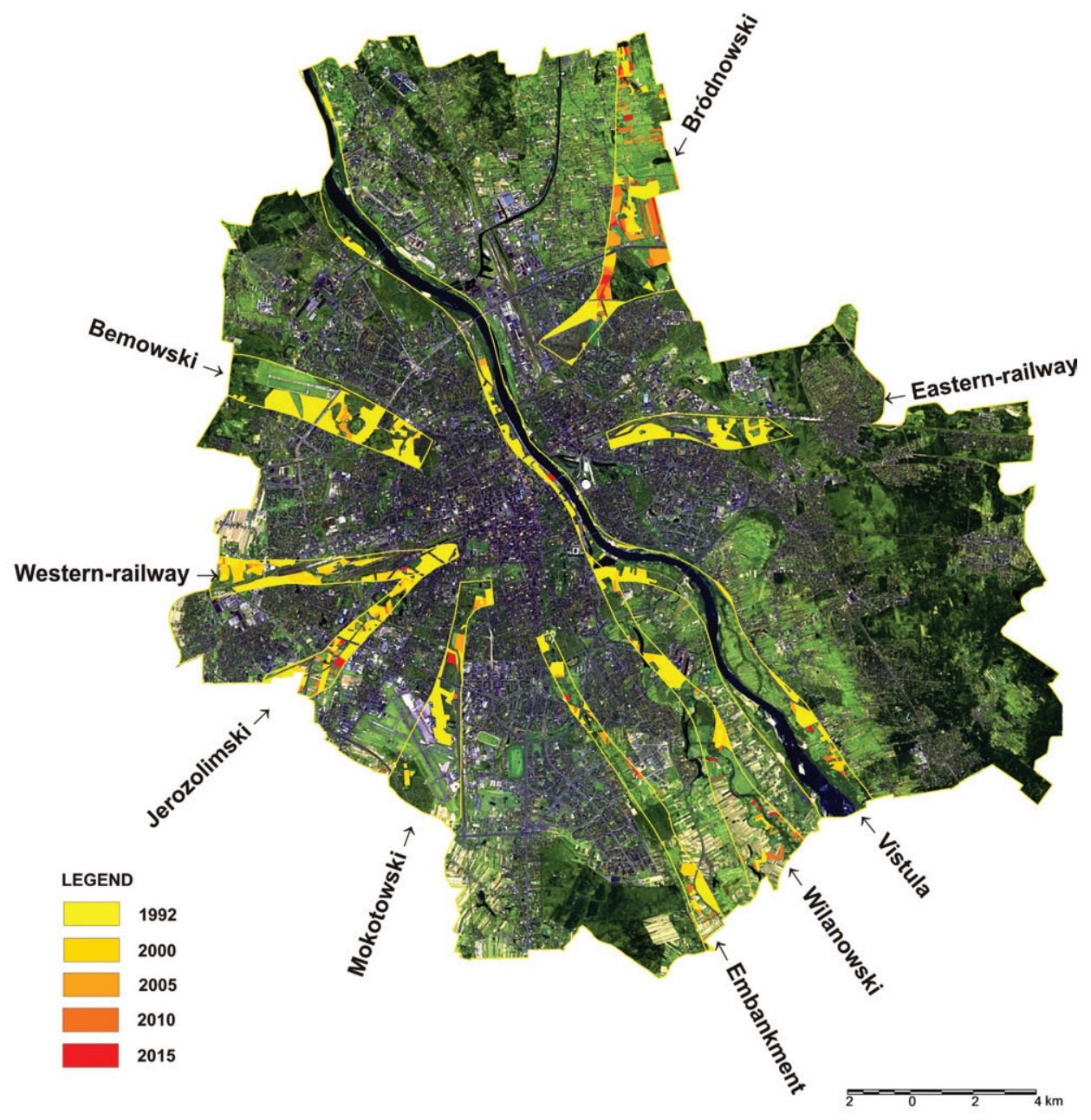

Figure 4. Changes in the development of the ventilation wedge system in Warsaw over the years 1992 to 2015 against the background of a satellite image from LANDSAT OLI from April 23, 2015 

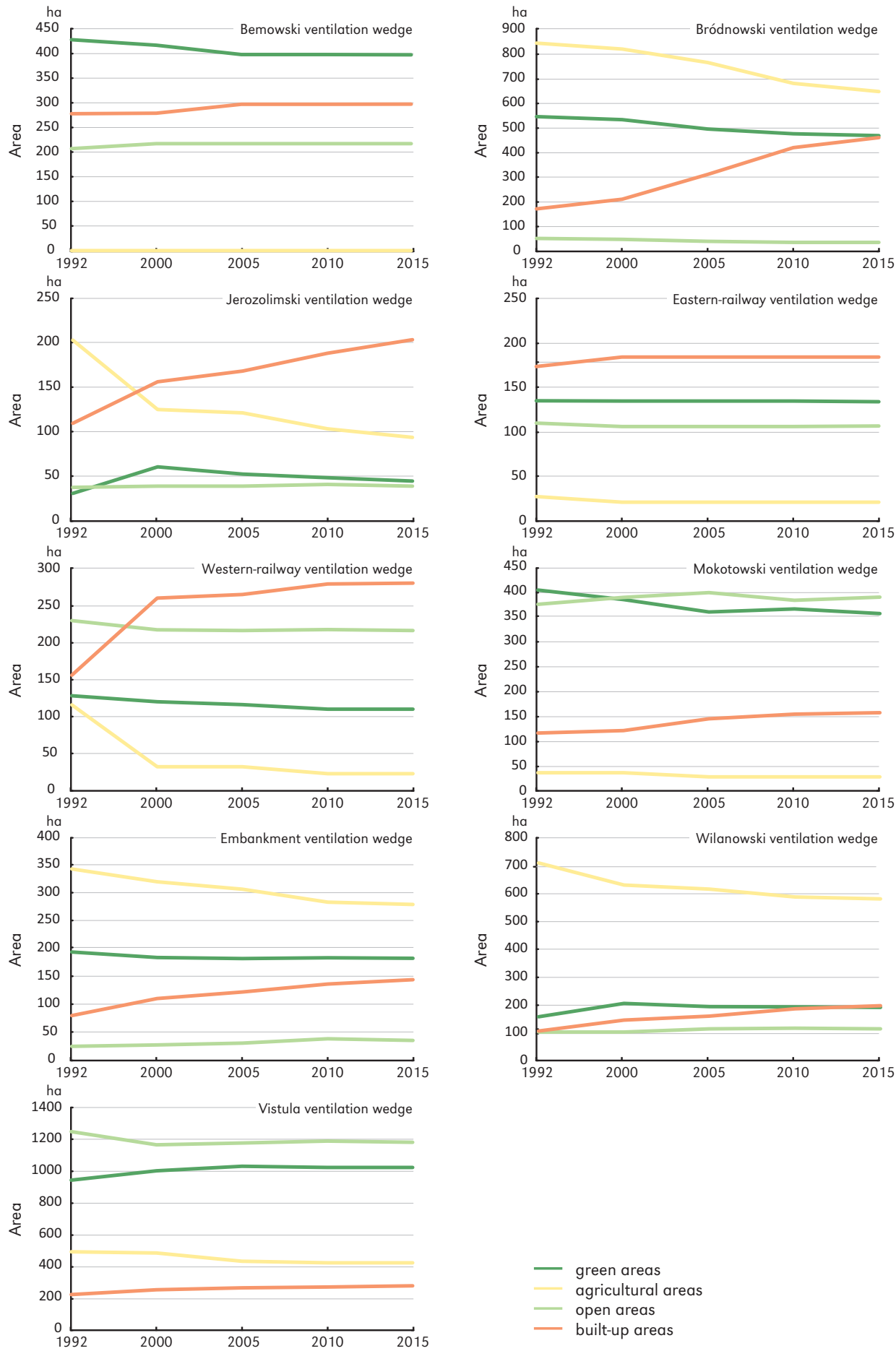

Figure 5. Changes in land use within the area of the ventilation wedges in Warsaw over the years 1992 to 2015 
shrank by $11 \%$ in comparison with the state in the year 2005. The changes within this ventilation corridor seem to be most intense and, beyond doubt, negative from the perspective of the ventilation and air regeneration system. During the period in question, the green areas diminished by $14 \%$ (77 ha) and agricultural land by $23 \%$ (197 ha).

Unlike in Bródnowski wedge, the most rapid changes in the Jerozolimski wedge occurred in the 1990s (Fig. 5). Up to the year 2000 the area of farming land decreased on average by 10 ha/year (over 38\% in comparison to the year 1992) and the built-up area expanded by 6 ha/year. It is also worth noting the increase in green areas during the same period which is the result of plant succession taking place on uncultivated land. In the next period between 2000 and 2005 a decline in the extent of green areas can be noted in favour of development. The rate of change increased in the years 2005-2015 but never reached the level of the 1990s. The built-up area expanded by $86 \%$ (94 ha) during the period analysed, though the agricultural land shrank by almost half (100 ha) and the green areas by $45 \%$ (14 ha). In 2005-2010 the area of open space grew slightly as a result of building an artificial ski slope and the preparation of some plots of land for further development.

The Western-railway wedge is characterised by a significant share of land used for railway transport, namely the track and associated infrastructure. Crucial changes occurred there in the 1990s (Fig. 5), when the development area was expanding by $13 \mathrm{ha} /$ year. It had therefore grown continuously, by 105 ha in total, between 1992 and 2000 while agricultural land had diminished by $84 \mathrm{ha}$, other open space by $12 \mathrm{ha}$, and green areas by 8 ha. The changes in the land use of this wedge since 2000 were insignificant. They didn't reach 5 ha for any individual category in the period of 2000-2005, which can be considered as a stagnation phase. However, increased urban development activity (an average of $2.9 \mathrm{ha} /$ year) was observed in the years that followed - 2005-2010, and consequently there was a decrease in the extent of green and agricultural areas (Fig. 5). The next period of stagnation occurred in the years 2010-2015. Summarising, in the period taken into consideration, the agricultural area decreased by $80 \%$ ( $93 \mathrm{ha}$ ), greenery by $14 \%$ (18 ha), and other open space by 6\% (13 ha), whilst the built-up area expanded by $80 \%$ (125 ha). In the Eastern-railway wedge, land use transformation only occurred in the 1990s. At this time the built-up area increased by $11 \mathrm{ha}$, while agricultural areas ( $6 \mathrm{ha}$ ) and open areas (3 ha) decreased.

The Mokotowski ventilation wedge is characterised by a large proportion of greenery and open space. In the period between 1992 and 2005 a decrease of green areas could be observed (especially allotment gardens) with, at the same time, an increase in the area of open space. However, the most significant changes occurred in the years 2000-2005 (Fig. 5). Then, the green areas were replaced by residential investments such as Eco Park and Marina Mokotów. The trend to development was clearly visible in the years 2005-2010, especially due to following stages of the Eco-Park development. However, the land previously used in the process of building Marina Mokotów was transformed into greenery in the year 2010. In conclusion, in the period 1992-2015 the area of greenery decreased by $11.7 \%$ (47 ha), agriculture by $22 \%$ ( $8 \mathrm{ha}$ ), while the open space and builtup area increased by ca. 4\% (14 ha) and 35\% (41 ha).

The most significant changes in the Embankment ventilation wedge took place during the period from 1992 to 2000 (Fig. 5). In this period the built-up area grew at the expense of the city's green areas at the rate of ca. 4 ha/year. Between 2000 and 2010 a similar trend can be observed though it was slower (2.6 ha/year). In 1992-2010 it can also be noted, that there was a slight growth in open space which accompanied the development of the Wilanów district. From 2005 to 2010 there was a decrease in the land used for farming (by $23 \mathrm{ha}$ ) and a growth in green areas, as well as the built-up area and the area 
currently under development (Miasteczko Wilanów). In the years 2010-2015 the increase in built-up area was lower (1.6 ha/year), which was mainly due to bank lending policies. In total, within those 23 years, the builtup areas increased by $81 \%$ ( $64 \mathrm{ha}$ ) and open space by $43 \%$ (10 ha) while farming land shrank by 64 ha and green areas by 11 ha (6\%).

Farming land accounted for more than half of the Wilanowski ventilation wedge. In the period covered by the analysis, its area continually decreased, especially between the years 1992 and 2000 (10 ha/year) (Fig. 5). The area was used for development or ceased to serve its previous role due to vegetation succession. Between 2000 and 2005 the rate of change decreased and it did not reach 3 ha/year. The open space increased by $11 \%$ as a result of the construction of the Siekierkowska Route. It can therefore be noted that between 2005 and 2010 the green areas increased (ca. 5 ha/year) and agricultural land shrank (by nearly 6 ha/year). In 2010-2015, in the same manner as with the Embankment and Bródnowski ventilation wedges, there was a slowdown in the growth of the built-up area (2.2 ha/year). From the research conducted it is possible to draw the conclusion that, over 23 years, agricultural land decreased by 129 ha (18\% less than in 1992), however the following classes grew: green areas by $21 \%$ (34 ha), open space by $12 \%$ (12 ha), built-up area by $84 \%$ (90 ha).

In conclusion, the above analysis demonstrated that the built-up area expanded in the Bródnowski, Jerozolimski, Embankment and Wilanowski ventilation wedges. The most rapid changes occurred in the Jerozolimski and Western-railway wedges in the 1990s, and in the Bemowski and Mokotowski wedges between 2000 and 2005, and their more recent development is significantly slower. The most intensive changes are currently observed in the Bródnowski wedge and these have been happening there since 2000 . Since 2010 the pace of development of the Bródnowski, Jerozolimski, Embankment and Wilanowski wedges decreased significantly, but it is not due to spatial planning policy. The main reason was a change in the policy concerning mortgage loans. Due to the world financial crisis in 2007, Polish banks have tightened the criteria for granting mortgage loans.

\section{Analysis of the possible causes of the trends observed above}

Spatial planning is an important instrument in climate preservation. "Strategic Concepts of Conditions and Directions of Spatial Development of Warsaw" with amendments (Warsaw City Council 2006) is a document establishing the current development policy in the capital city. It defines the current extent of ventilation corridors and their future development. Comparing it with the "General Zoning Development Plan of the Capital City of Warsaw" from 1992 showed that the total area of the ventilation corridors was reduced by nearly 1300 ha. This particularly concerns specific wedges such as the Western-railway (46\%), Eastern-railway (52\%), and Bemowski $(57 \%)$ wedges, from which already builtup areas had been excluded. Analysing the borders of the wedges it can be concluded, that spatial policy in Warsaw was adjusted to the existing state and maintaining the status quo. What is more, substantial changes in the field of spatial planning occurred in the period in question which resulted in the lack of a legal obligation to prepare local zoning plans (pol. MPZP) for the entire city. Even though preparation of the "The Strategic concepts..." (Warsaw City Council 2006) is compulsory, it doesn't have local legal status. Therefore, in cases where no local zoning plan exists or is binding, building permits are issued on the basis of outline planning principles and the location of public purpose. Up until this day some parts of Warsaw's ventilation and air regeneration system are not covered by local zoning plans, which is especially important in the case of such ventilation corridors as Bemowski, Jerozolimski, Mokotowski and Eastern-railway. As an effect, those areas are subject to chaotic development 
based only on outline planning decisions, which often leads to major landscape transformations.

Analysis of the local zoning plans in force in the years 1992-2015 proved that some of them did not maintain continuity with the previous documents and that they encouraged building on ventilation wedges - which meant building barriers interfering with proper air flow and consequently with ventilation. Usually buildings within ventilation corridors cannot exceed 12-15 m, however local zoning plans from 1998 and later allowed the erection of buildings up to $25 \mathrm{~m}$ high (e.g. Mokotowski wedge), $35 \mathrm{~m}$ (Bródnowski wedge) and even $40 \mathrm{~m}$ (Bemowski wedge). As far as the Embankment wedge is concerned, what seems surprising is that buildings $11 \mathrm{~m}$ high can be erected on its entire area, while in the narrowest point they can even reach 25 metres, which means that a mechanical barrier can be built. Such a barrier may inhibit proper airflow.

Analysis of the ownership structure of land located within the ventilation and air regeneration system in Warsaw (January 2012 status) proved that private land constitutes $44 \%$ of the area, while State owned property was $37 \%$ and property owned by Warsaw City Council only $14 \%$ of the area. There is a significant prevalence of State property in the wedges: Bemowski (59\%), Eastern-railway (69\%), Western-railway (46\%) and Mokotowski (53\%). However, the majority of property is private within other wedges: Bródnowski (72\%), Jerozolimski (69\%), Embankment (53\%) and Wilanowski (59\%). It is worth mentioning, that the built-up area increased in those ventilation corridors where the share of private property was the largest (Wilanowski, Embankment, Bródnowski). In the corridors where the majority of land belonged to the State, the changes mainly occurred between 1992 and 2000 and the majority of them were connected with the construction of road and railway infrastructure. The change which took place in 2000-2015 in the Bemowski, Jerozolimski, Western-railway, Mokotowski and Embankment wedges seems worrying.
The Eco-physiographic study (Warsaw City Council 2006) includes a recommendation to leave these areas untransformed, and even prohibits introducing further development. Ignoring the suggestions to refrain from transforming the area of the ventilation corridors poses a threat to the proper functioning of the city's ventilation and air regeneration system. However, the analysis here proves that the Bemowski and Mokotowski wedges were mainly built over in the period between 2000 and 2005, therefore after the suggestions mentioned above were prepared and published. Later transformations were less extensive. On the other hand, in Jerozolimski, Western-railway and Embankment wedges the changes occurred between 1992 and 2000 and between 2005 and 2010 . In those corridors the green area decreased by 65 ha in the period 2005-2015, with agricultural land decreasing by $678 \mathrm{ha}$, though the built-up area increased by 778 ha. The analysis above takes into consideration the extent of the wedges described in the plan from 1992, not the ones prepared in 2006. Nevertheless severe negative changes in the ventilation and air regeneration system in Warsaw have been in progress since 2001. What is more, the location and height of particular buildings as well as the total extent of the built-up area appears to have a crucial significance for the operation of the system (Capeluto et al. 2003; Wong et al. 2010; Suder \& Szymanowski 2014).

According to the Eco-physiographic study attached to the "Strategic Concepts of Conditions and Directions of Spatial Development of Warsaw" (Warsaw City Council 2006), the wedges which are relatively unspoilt and which fulfil their function well are the Vistula River Valley and Eastern-railway. In the Bemowski and Mokotowski wedges a reduction or even stagnation in development can be noted. However, both corridors were classified in 2001 as those where it was necessary to prevent further changes, while Mokotowski was even believed to be the most transformed (especially in 2000-2005) and under the most accelerated development 
(Naftprojbud 2001). In the remaining ventilation corridors, a trend to develop gradually can be observed, especially in those where the share of agricultural land is the largest, namely Bródnowski and Wilanowski. The gradual and constant degradation of ventilation wedges (including Jerozolimski and Western-railway, which were the most developed) seems also to be important for the formation of the city's climate. As was stated in the Polish Architects Society (SARP) conference in 2004, development on ventilation corridors had, even in the year 2004, caused significant damage in some city districts in terms of the ventilation and air regeneration system.

\section{Conclusion}

The aim of this paper was to establish the directions and rate of development change in ventilation corridors in Warsaw and to analyse its causes. The research conducted proved that negative and potentially harmful processes occur within the area of the entire ventilation and air regeneration system. Expansion of the built-up areas within the ventilation corridor system was mainly at the expense of agricultural areas. In 1992 the built-up area amounted to $15 \%$ while in 2015 it was as much as $23 \%$ of the total area of the ventilation wedges. The rate of the process in the whole capital city is stable, though it differs in particular corridors. This situation is a result of several processes. This research leads to the conclusion that this huge asset for Warsaw - the system of ventilation and air regeneration - is under threat. It has been the case since the 1990s when a new legal and political framework was established.
The introduction of a free market in real estate after the transformation influenced the acceleration of the development of the ventilation wedges. The analysis of planning and strategic documents proved that policy on this problem has not been consistent throughout the whole period in question, as in particular cases the development of the wedges was allowed. A number of successive revisions of "Strategic Concepts of Conditions and Directions of Spatial Development of Warsaw" (2009, 2013, 2014) were prepared without any assessment of the operation of the ventilation and air regeneration system, which, as a result, renders an assessment of the development principles of the whole city impossible. The fact that local zoning plans are not mandatory results in a low percentage of the city's area being covered by them, and thus urban development within the ventilation corridors occurs in a chaotic manner, based on outline planning decisions issued by local government. The impact of the ventilation wedge system in Warsaw on the intensity of the urbanisation process was mainly associated with factors connected to the situation regarding financial and living conditions in Poland (an increase in the affluence of society, availability of mortgage loans). Assuming that there are no changes in the field of spatial planning, the current situation will worsen and might lead to further degradation of the ventilation and air regeneration system in Warsaw.

Editors' note:

Unless otherwise stated, the sources of tables and figures are the authors', on the basis of their own research. 


\section{References}

Arnfield A.J., 2003. Two decades of urban climate research: A review of turbulence, exchanges of energy and water, and the urban heat island. International Journal of Climatology, vol. 23, no. 1, pp. 1-26.

BŁAŻEJCZYK K., 2002. Znaczenie czynników cyrkulacyjnych i lokalnych w kształtowaniu klimatu i bioklimatu aglomeracji warszawskiej. Dokumentacja Geograficzna, vol. 26, Warszawa: Instytut Geografii i Przestrzennego Zagospodarowania PAN.

BotTema M., 1997. Urban roughness modelling in relation to pollutant dispersion. Atmospheric Environment, vol. 31, no. 18, pp. 3059-3075.

Capeluto I.G., Yezioro A., Shaviv E., 2003. Climatic aspects in urban design - a case study. Building and Environment, vol. 38, no. 6, pp. 827-835.

ChMielewski J.M., 2001. Teoria urbanistyki w projektowaniu i planowaniu miast. Warszawa: Oficyna Wydawnicza Politechniki Warszawskiej.

FortuniaK K., KŁYsIK K., 2008. Osobliwości klimatu miast na przykładzie Łodzi [in:] K. Kłysik, J. Wibig, K. Fortuniak (eds.), Klimat i bioklimat miast. Łódź: Wydawnictwo Uniwersytetu Łódzkiego, pp. 477-488.

Gaffin S.R., Rosenzweig C., Khanbillyardi R., Parshall L., Mahani S., Glickman H., Goldberg R., Blake R., Slosberg R.B., Hillel D., 2008. Variations in New York city's urban heat island strength over time and space. Theoretical and Applied Climatology, vol. 94, no. 1-2, pp. 1-11.

General Zoning Development Plan of the Capital City of Warsaw, 1992. Warsaw Development Planning Office J.S.C.

Haeger-Eugensson M., Holmer B., 1999. Advection caused by the urban heat island circulation as a regulating factor on the nocturnal urban heat island. International Journal of Climatology, vol. 19, no. 9, pp. 975-988.

Howard E., 1898. To-morrow: A peaceful path to real reform. London: Swan Sonnenschein \& Co.

HoWARD L., 1818-1820. The Climate of London, deduced from meteorological observations, made at different places in the neighbourhood of the metropolis, vol. 1, 2. London: W. Phillips, G. Yard.

Jankiewicz A., Poręibska-Srebrna J., 2005. Tradycje urbanistyczne Warszawy [in:] W. Fałkowski (ed.), Straty Warszawy 1939-1945. Raport. Warszawa: Miasto Stołeczne Warszawa, pp. 34-59.

KICIŃSKA B., WaWER J., 2010. Wpływ urbanizacji na warunki klimatyczne w Warszawie [in:] M. Stopa-Boryczka, J. Boryczka, J. Wawer, M. Dobrowolska, M. Osowiec, E. Błażek, J. Skrzypczuk (eds.), Klimat Warszawy i miejscowości strefy podmiejskiej, ser. Atlas współzależności parametrów meteorologicznych i geograficznych w Polsce, vol. 24, Warszawa: Wydawnictwa Uniwersytetu Warszawskiego, pp. 279-298.

Kossowska-Cezak U., 1998. Wpływ rozwoju terytorialnego Warszawy na warunki termiczne. Acta Universitatis Lodziensis, Folia Geographica Physica, vol. 3, pp. 51-57.

Kossowska-Cezak U., Bareja P., 1998. Wptyw zabudowy miejskiej Warszawy na kierunek i prędkość wiatru. Acta Universitatis Lodziensis, Folia Geographica Physica, vol. 3, pp. 463-465.

Kotaszewicz T., 1994. Koncepcje przestrzennego rozwoju Warszawy w pracach Tadeusza Tołwińskiego 1916-1946, ser. Krajobraz Warszawski, 3, Warszawa: Urzad Gminy Warszawa-Centrum.

Królikowski L., Ostrowski M., 2009. Rozwój przestrzenny Warszawy. Warszawa: Agencja Wydawnicza EGROS.

LANDSBERG H.E., 1981. The urban climate. International Geophysics Series, vol. 28, New York: Academic Press.

LEWIŃSKA J. (ed.), 1991. Klimat miasta. Vademecum urbanisty. Kraków: Wydawnictwo Secesja.

LI Q., Kobayashi M., Wakayama Y., Inagaki H., Katsumata M., Hirata Y., Hirata K., Shimizu T., Kawada T., Park B.J., Ohira T., Kagawa T., MIYAZAKI Y., 2009. Effect of phytoncide from trees on human natural killer cell function. International Journal of Immunopathology and Pharmacology, vol. 22, no. 4, pp. 951-959.

LI Q., Nakadal A., Matsushima H., Miyazaki Y., Krensky A.M., Kawada T., Morimoto K., 2006. Phytoncides (wood essential oils) induce human natural killer cell activity. Immunopharmacology and Immunotoxicology, vol. 28, no. 2, pp. 319-333.

Lorenc H., MazUr A., 2003. Wspótczesne problemy klimatu Warszawy, ser. Atlasy i Monografie, Warszawa: Instytut Meteorologii i Gospodarki Wodnej. 
Malisz B., 1981. Zarys teorii kształtowania układów osadniczych. Warszawa: Arkady.

Meadows D.H., Meadows D.L., Randers J., BehRENS III W.W., 1972. The Limits to Growth. New York: Universe Books.

NaftProjbud, 2001. Ocena funkcjonowania systemu przewietrzania i regeneracji powietrza [in:] Biuro Naczelnego Architekta Miasta, Opracowanie ekofizjograficzne do studium uwarunkowań i kierunków zagospodarowania przestrzennego, http://architektura.um.warszawa.pl/sites/ default/files/files/Zal_Nr_III.12.pdf [7 March 2016]

OKE T.R., 1981. Canyon geometry and the nocturnal urban heat island: Comparison of scale model and field observations. International Journal of Climatology, vol. 1, no. 3, pp. 237-254.

OKE T.R., 1982. The energetic basis of the urban heat island. Quarterly Journal of the Royal Meteorological Society, vol. 108, no. 455, pp. 1-24.

OKE T.R., 1987. Boundary layer climates. London: Methuen.
SKORUPSKI J., 2000. Rozwój Warszawy i powiększanie się "warszawskiego" odcinka Wisły [in:] J. Lickiewicz, J. Pawlak, W. Pietrusiewicz (eds.), Wisła w Warszawie. Warszawa: Dom Wydawniczy ELIPSA, pp. 139-153.

Suder A., Szymanowski M., 2014. Determination of ventilation channels in urban area: A case study of Wrocław (Poland). Pure and Applied Geophysics, vol. 171, no. 6, pp. 965-975.

Voogt J.A., 2002. Urban Heat Island [in:] T. Munn, I. Douglas (eds.), Encyclopedia of Global Environmental Change, vol. 3, Chichester: Wiley, pp. 660-666.

Warsaw City Council, 2006. Strategic Concepts of Conditions and Directions of Spatial Development in Warsaw. Legal act No LXXX/2746/2006 October 10, 2006, http://www.architektura. um.warszawa.pl/tekst-studium [7 March 2016].

Wong M.S., Nichol J.E., To P.H., Wang J., 2010. A simple method for designation of urban ventilation corridors and its application to urban heat island analysis. Building and Environment, vol. 45, no. 8, pp. 1880-1889.
(C) Katarzyna Osińska-Skotak • Joanna Zawalich

(C) Geographia Polonica

(C) Institute of Geography and Spatial Organization

Polish Academy of Sciences • Warsaw • 2016
Article first received • July 2014 Article accepted • February 2016 